\title{
Two Plans of Folke Bernadotte — First Attempts to Search for Peace
}

\author{
Anna N. Osipenko
}

\begin{abstract}
Soon after the first Arab-Israeli war began the United Nations Mediator in Palestine was empowered. This post was taken up by the Swedish diplomat Count Folke Bernadotte. Bernadotte made a significant personal contribution to conflict resolution in Palestine promoting cease fire by the summer 1948 and delivering suggestions as the basis for a peace accord between the parties. His mission represented the first institutional attempt of the international community to resolve one of the most acute disputes in the modern world. Its significance cannot be underestimated, and it deserves being carefully described so that the initial stage and the foundation of the decision-making process in Palestine could be analyzed. The summer 1948 realities proved the first aggregate of Bernadotte's suggestions was non-viable. The detailed estimate of the situation in Palestine and the principled positions of the parties resulted in the Second plan of Folke Bernadotte. Bernadotte fervently insisted that imposing the tough course of conflict resolution exceeded UN Mediator's authority. He only aimed at forming the foundation of a possible compromise. Nevertheless, the Second plan didn't gain traction as well, and Count Folke Bernadotte was assassinated by the militants of a Jewish extremist group. Thus, Bernadotte's flexible stand didn't prevent him from taking the wrong tack in reconciliation process. The paper below is devoted to advising which mistakes committed by UN Mediator in Palestine should be taken into consideration in the future.
\end{abstract}

Index Terms-Arab-Israeli conflict, bernadotte plan, history of world diplomacy, united nations organization.

\section{INTRODUCTION}

The Arab-Israeli conflict has been remaining on the agenda of the United Nations Organization and all the structures and bodies responsible for world peace and security for decades. Being one of the most urgent and controversial problems impeding stability in the Middle East, it strongly needs wise and sophisticated approach, scrupulous and profound analysis and the fastest resolution possible. However, the implacable fact is that by the present moment the way out has not been found, which presumably implies the peace process has to some extent taken the wrong way. To look back at the history of the conflict resolution in Palestine means to seek further possibility to understand where mistakes were committed.

The paper below is devoted to the first institutional attempt of the United Nations to reconcile the Arab-Israeli dispute that eventually leads into failure. This attempt was made by

Manuscript received May 24, 2015; revised July 23, 2015

A. N. Osipenko is with National Research University Lobachevsky State University of Nizhni Novgorod, 603950 Russian Federation (e-mail: searchforwisdom@gmail.com)
Count Folke Bernadotte, a Swedish diplomat appointed UN Mediator in Palestine in May 1948. The two reconciliation plans of Count Bernadotte were fervently denied by the parties to the conflict and brought no tangible results. The main aim of this paper is to describe the two plans of Bernadotte on the basis of his progress report to UN Secretary General and clearly distinct the framework of fruitless attempt of reconciliation between Arabs and Jews so that the mistakes made could be taken into consideration when shaping the peace process in the future.

It seems unquestionable, however, that the struggle for peace in Palestine can and must continue taking into account this unsuccessful experience.

\section{BeginNing OF THE Mission}

The State of Israel was declared independent on May 14th, 1948 , which was the logical continuation of UN General Assembly Resolution 181 [1] on the partition of mandated Palestine. The Palestine partition plan was fervently denied by the Arab world that proclaimed war upon its newly minted neighbour. The beginning of the Arab-Israeli war forced the UN General Assembly to empower in Resolution 186 (S-2) of May 14th, 1948 [2] a United Nations Mediator in Palestine. The key functions of the Mediator were named as follows:

- Use of good offices with the local and community authorities in Palestine to provide the safety and well-being of the population, assure the protection of the Holy Places and other religious sites, and promote a peaceful adjustment of the situation of Palestine.

- Cooperation with the Truce Commission for Palestine appointed by the Security Council in its resolution of April 23rd, 1948 [3];

- Invitation of the assistance of appropriate specialized agencies of the United Nations and other governmental or non-governmental organizations of a humanitarian and non-political character with a view to the promotion of the welfare of the inhabitants of Palestine.

It was Folke Bernadotte, Count of Wisborg, a diplomat, public figure and the member of the Swedish royal family, who was appointed UN Mediator in Palestine. Bernadotte's mission became of undoubted interest for a number of eminent researchers and biographers [4]-[6]. It is of no doubt that the active mediatory efforts of Count Bernadotte played a remarkable role at the initial phase of the Arab-Israeli conflict: at the end of May 1948 the four-week cease fire agreement was reached that came into force on June 11th. Immediately after his arrival in Cairo Count Bernadotte proceeded to establishing the effective dialogue between the parties and elaborating suggestions that were to underlie the 
peace accord. In his progress report submitted to UN Secretary General Bernadotte gave his estimate of the existing situation, underlined the exceptional importance of the moment at hand and claimed that for a number of reasons the crucial stage was reached in the UN Mediator work.

\section{First Plan of BernadotTE}

On June 27th, 1948 Count Folke Bernadotte sent Letter S/863 [7] to UN Secretary General containing his suggestions on the conflict resolution in Palestine. These suggestions were conventionally named the First Plan of Folke Bernadotte. There is no shared vision of the importance of this document, as well as of the Second, final plan of Bernadotte. One point of view is that the UN Mediator suggestions allegedly being prominently pro-Arab would have acquired nearly the force of law for the parties at odds in case they had been approved by the international community. However, Folke Bernadotte himself repeatedly highlighted that he saw the role of UN Mediator not in rendering final decisions on the future of Palestine, but in generating proposals able to form the basis of the search of points of coincidence of parties' interests and the foundation for the peace accord appropriate for everyone. Taking into account such principled position was asserted in practically every document issued from UN Mediator's and supported all suggestions contributed by Bernadotte, there appear no ample grounds to be in doubt about the fact that both the First and the Second plan were in no way designed to infringe upon the interests of one or both parties of the conflict in Palestine.

Letter S/863 was composed of three documents: introductory statement, suggestions presented by the Mediator on Palestine and annex concerning the territorial matters of the proposed solution to the problem.

Introductory statement concerned the interpretation of UN Mediator's role in the conflict resolution in Palestine, estimate of the existing situation and the character of the suggestions presented aimed at providing a stable foundation for the negotiations between the parties at war, but in no way pretending to be immediately enacted as a mandatory resolution.

In the capacity of a probable basis for discussion Count Bernadotte proposed the following:

1) Subject to the willingness of the directly interested parties to consider such an arrangement, Palestine, as defined in the original Mandate entrusted to the United Kingdom in 1922, that is including Transjordan, might form a Union comprising two members, one Arab and one Jewish.

2) The boundaries of the two members will be determined in the first instance by negotiation with the assistance of the Mediator and on the basis of suggestions to be made by him. When agreement is reached on the main outlines of the boundaries, they will be definitively fixed by a Boundaries Commission.

3) The purposes and function of the Union should be to promote common economic interests, to operate and maintain common services, including customs and excise, to undertake development projects and to co-ordinate foreign policy and measures for common defense.

4) The functions and authority of the Union might be exercised through a central council and such other organs as the members of the Union may determine.

5) Subject to the provision of the Instrument of Union, each member of the Union may exercise full control over its own affairs including its foreign relations.

6) Immigration within its own borders should be within the competence of each member, provided that following a period of two years from the establishment of the Union, either member would be entitled to request the Council of the Union to review the immigration policy of the other member and to render a ruling thereon in terms of the common interests of the Union. In the event of the inability of the Council to reach a decision on the matter, the issue could be referred by either member to the Economic and Social Council of the United Nations whose decision, taking into account the principle of economic absorptive capacity ${ }^{1}$, would be binding on the member whose policy is at issue.

7) Religious and minority rights should be fully protected by each member of the Union and guaranteed by the United Nations.

8) Holy Places, religious buildings and sites should be preserved and existing rights in respect of the same should be fully guaranteed by each member of the Union.

9) Recognition should be accorded to the right of residents of Palestine who, because of conditions created by the conflict there have left their normal places of abode, to return to their homes without restriction and to regain possession of their property.

With regard to paragraph 2 of the suggestions it was considered that certain territorial arrangements might be worthy of consideration:

1) Inclusion of the whole or part of the Negev in Arab territory.

2) Inclusion of the whole or part of Western Galilee in Jewish territory.

3) Inclusion of the City of Jerusalem in Arab territory, with municipal autonomy for the Jewish community and special arrangements for the protection of the Holy Places.

4) Consideration of the status of Jaffa.

5) Establishment of a free port at Haifa, the area of the free port to include the refineries and terminals.

6) Establishment of a free airport at Lydda.

On June 28th, 1948 the above mentioned three documents were submitted to the Arab authorities and the Provisional Government of Israel.

\footnotetext{
${ }^{1}$ This principle was enacted in Churchill White Paper of 1922, the first of six documents issued by the British government that concerned trusteeship Palestine. The principle stipulated one of the factors influencing the immigration quota for Jews in Palestine: the immigration must not reach the size exceeding the capacity of economy to absorb those newly arrived; it must be guaranteed that immigrants do not become a burden for the people already residing in Palestine and deprive of job places any of the sectors of the existing population.
} 


\section{REVISION OF SUGGESTIONS}

The suggestions of Count Bernadotte that he called "a general framework within which a reasonable and workable settlement might have been reached, had the two parties concerned been willing to discuss them" were fervently denied by both the Arabs and the Jews. Since these suggestions were presented on the clearly expressed condition that they must be considered entirely tentative and were designed above all to elicit the points of view and counter-proposals of the parties, and they should be put into practice only with their consent, UN Mediator never insisted on them. Since he had submitted them in writing to the Arab and the Jewish authorities on June 27th, 1948 and until submitting Progress report A/648 [8] to UN Secretary General on September 16th, 1948 Bernadotte presented no official suggestions for the definitive settlement. However, in written correspondence and verbal communication Folke Bernadotte repeatedly freely exchanged ideas on this matter with the Arab authorities and Tel Aviv. As a result, he drew conclusion that the basic concept concerning the creation of the economic and political Union in Palestine was non-viable. In his opinion, the time was obviously inappropriate to bring such a scheme to life.

That is why the First plan of Bernadotte was subject to revision. The main reason for that conditioning substantial difference between the time of adopting UN Resolution of November 29th, 1947 and the summer of 1948 was the fact that "a war has been started and stopped and that in the intervening months decisive events have occurred". The most important of them was undoubtedly the declaration of independence of the State of Israel.

The detailed estimate of the situation in Palestine in summer 1948 was given by Folke Bernadotte in the progress report A/648 of September 16th, 1948 of the UN Mediator in Palestine submitted to the UN Secretary General. Bernadotte named the four basic issues fundamentally influencing the course of the Arab-Israeli conflict: partition of Palestine, the status of the Jewish State, the issue of Jewish immigration and the problem of Arab refugees. In Bernadotte's opinion, the formal attitudes of the parties on the first three of those issues had not changed since the adoption of Resolution 181. However, it was unquestionable that, there had been very significant changes in the Palestine scene in the intervening months, and thus some of the prevalent attitudes to conflict resolution proved quite unrealistic and ineffective.

Both UN General Assembly Resolution of November 29th, 1947 and the First plan of Folke Bernadotte suggested the partition of Palestine, the creation of the Arab and the Jewish states forming a Union, and granting the status of an international city under the UN auspices to Jerusalem. Due to uncertainty concerning the economic viability of the Arab state and Jerusalem, the integration of the three subjects into the Economic union of Palestine was intended to adjust possible disproportion resulting from the territorial partition.

According to Bernadotte's estimate, the creation of a viable economic union was possible only in case there existed, or there could be fostered or induced by the authorities, a willingness on the part of both Arabs and Jews in Palestine to cooperate. However, the chain of unfortunate events which began in Palestine almost immediately after Resolution 181 had been adopted demonstrated not only that the lack of this necessary Arab willingness, but also a categorical antagonism provoking "virtual civil war even before the termination of the Mandate on May 15th, 1948". In ten months since the adoption of Resolution 181 it had become increasingly clear that any plan based on the assumption of immediate cooperation between Arabs and Jews in Palestine would be doomed because it would ignore the harsh realities of existing relationships. Thus, the issue of expedience of the revision of UN General Assembly Resolution of November 29th, 1947 was removed from the agenda by the very facts of the recent history of Palestine unfolding before UN Mediator's eyes.

The new conclusions and suggestions of Folke Bernadotte in Palestine were based on the following seven fundamental premises listed in Progress report A/648:

1) Peace must return to Palestine. The objective necessity existed that every feasible measure should be taken to ensure that hostilities will not be resumed and that harmonious relations between Arab and Jew will ultimately be restored.

2) A Jewish State called Israel existed in Palestine. There were no sound reasons for assuming that it would not continue to do so.

3) The boundaries of this new State must finally be fixed either by formal agreement between the parties concerned or failing that, by the United Nations Organization.

4) Adherence to the principle of geographical homogeneity and integration, which should be the major objective of the boundary arrangements, should apply equally to Arab and Jewish territories. Their frontiers should not therefore be rigidly controlled by the territorial arrangements envisaged in Resolution of November 29th, 1947.

5) The right of innocent people, uprooted from their homes by the present terror and ravages of war, to return to their homes, should be affirmed and made effective, with assurance of adequate compensation for the property of those who may choose not to return.

6) The City of Jerusalem, because of its religious and international significance and the complexity of interests involved, should be accorded special and separate treatment.

7) International responsibility should be expressed where desirable and necessary in the form of international guarantees, as a means of allaying existing fears, and particularly with regard to boundaries and human rights.

\section{Situation as Viewed by the MediatoR}

It is obvious that the cited seven premises reflected the above mentioned four basic factors having fundamental impact on the course of the Arab-Israeli conflict that were named by Bernadotte in Progress report A/648: partition of Palestine, the status of the young Jewish State, Jewish immigration and the future of Arab refugees.

In respect of the State of Israel the position of UN Mediator in Palestine was principled: its creation and the 
declaration of its independence was a given fact that could not be denied. The fact that the Jewish State was a living, solidly entrenched and vigorous reality was named by Bernadotte the most significant development in the Palestine scene since November 1947. It enjoyed de jure or de facto recognition from an increasing number of States, two of them being permanent members of the Security Council, which Bernadotte thought was an incidental but arresting fact The Provisional Government of Israel was exercising at that time, without restrictions on its authority or power, all the attributes of full sovereignty.

The Jewish State was not born in peace as was hoped for in Resolution 181, but rather, like many other states on the planet, in violence and bloodshed. The establishment of this State constituted the only implementation given to Resolution 181, and even this was accomplished by a procedure quite contrary to that envisaged for the purpose in the resolution. Folke Berndaotte acknowledged that "in establishing their State within a semi-circle of gunfire, the Jews have given a convincing demonstration of their skill and tenacity". In his Report S/888 to the Security Council of July 12th, 1948 [9] he named the Jewish State "a small State, precariously perched on a coastal shelf with its back to the sea and defiantly facing on three sides a hostile Arab world. Its future may be assessed as uncertain, and if it survives this war its security will be likely to present a serious problem for a good time to come..."

But whatever the future might hold for the infant Jewish State, the inescapable conclusion was drawn that by the summer 1948 it was actually in existence and fully sovereign and that Arab determination to eliminate it could be realized only by armed force in sufficient strength to overwhelm it. The resort to armed force as a means of settling the problem had been prohibited by the Security Council.

Since its inception on the termination of the Mandate the most pressing need of the Jewish State had been the opportunity to consolidate its position, both internally and externally, and to perfect its administrative and political organization. Folke Bernadotte wrote that, "born in the throes of war, its road was instantly difficult". The two truces ${ }^{2}$ had been of especial advantage to the Provisional Government of Israel because these periods of relative peace afforded it a necessary opportunity for consolidation and organizational development. The main conclusion of UN Mediator in Palestine on this issue was that, being a new organism of limited resources and hoping for development, the State of Israel very largely depended in the long run on the cultivation of peaceful and mutually trusting relations with the neighbouring Arab States whose overwhelming numbers dwarfed into insignificance any population total to which the Jewish State might aspire. In other words, what Israel needed most was peace.

The Arabs in their turn, including not only Palestinian Arabs, but those of the seven Arab States, found it extremely difficult to accept even the fact the Jewish State existed in Palestine. While recognizing the right of many Jews in

\footnotetext{
${ }^{2}$ The four-week truce from June $11^{\text {th }}$ to July $9^{\text {th }} 1948$ and the truce on the resolution of UN Security Council that began on July $15^{\text {th }} 1948$.
}

Palestine to be there and to remain there as citizens of a Palestinian State, they bitterly rejected Jewish nationalistic aspirations for a separate State. The employment of force in Palestine by the Arab States was named a tragic mistake, but Folke Bernadotte didn't put in question the fact that resorting to this extreme action and willing to run the risk of thus offending the international community was in itself a measure of the intensity of the Arab feeling on the question.

In his Report A/648 Count Bernadotte stated it was fruitless to conjecture whether Arabs or Jews might have won a decisive victory in Palestine had international intervention not brought the fighting to a halt. Jewish forces might have won more territory in Palestine or even all of Palestine, but they could not have conquered the Arab States nor won peace with them. Arab armies by sheer force of numbers, might in time have pressed the Jews to the wall of the sea but, in Bernadotte's opinion, there was no indication they could muster sufficient strength to deliver a mortal blow, and it might well be doubted that this could have been accomplished in view of probable international intervention. Had the war continued it would most likely have ended in a stalemate, which in itself would have amounted to a Jewish victory. But the United Nations had firmly determined that the war could not go on and that the Palestine dispute had to be settled by peaceful means. And that was the Arab dilemma. The Jewish State, established under the cloak of United Nations authority, could be eliminated only by force. The United Nations, however, had decreed that force must not be employed. Therefore, the Arab States had to either resign themselves to the presence of the Jewish State or pursue the reckless course of defying the United Nations and thereby incurring liabilities the full burden and danger of which could not be calculated in advance.

The combination of Jewish strength and international intervention solved the issue in favour of the Jewish State. That is why in search of a stable foundation of peaceful conflict resolution in Palestine Folke Bernadotte suggested both the international community and the Jews of Israel should be more understanding of the Arab viewpoint, in no way justifying, nevertheless, the armed intervention of the Arab states. Bernadotte was assured such understanding would have a positive impact on solving the problem. The Arabs looked upon the nationalistic Jews of Palestine as interlopers and aggressors. They pointed to the fact that the Arab population was the preponderant population of the country and that it had been an Arab country for many centuries. Thus, in their fervour they not only rejected the historical claims of the Jews but also the legal basis for their presence in Palestine which the terms of the Mandate had provided.

The Arabs also reacted severely to Jewish immigration into Palestine which they regarded as a threat to the Arabs in the whole of Palestine and Transjordan as well. In accordance with the principle of economic absorptive capacity they harboured grave fears that the Jewish State in Palestine will not stay within its defined boundaries, and through population pressure resulting from unlimited immigration, encouragement and support from the world Jewry, as well as growing nationalism, a threat will be posed not only to Palestine but to the entire Arab Near East. 
A tolerant approach offered by Count Bernadotte was to appreciate the Arab views and fears, although on appraisal they might in large measure be found extravagant and unfounded. Since the Arabs nurture such viewpoints, no settlement could be on solid foundations unless every reasonable reassurance possible was afforded them, not only by the Jewish State but by the United Nations.

By the moment described the Arab party had consistently advocated a unitary Arab State in Palestine, with full rights and guarantees for the Jewish minority, as the acceptable solution of the Palestine problem. In the light of developments since November 1947 the Arab position had become unrealistic. Bernadotte even opened a question whether such proposal had ever been likely to serve the best interests of Palestinian Arabs. At that late stage in the problem and in view of all the circumstances, the cantonal and federal state schemes, in his opinion, had no practical merit which would make them worthy of consideration. UN Mediator had no doubt that territorial, political and economic unity was highly desirable in Palestine and lacking such complete unity, some form political and economic, or at least economic, union would be a reasonable alternative. However, the existing antagonism between the Arab and Jewish communities rendered impractical the application of any such arrangements at least in the moment at hand.

The issue of Jewish immigration in the very nature of the case submerged in the larger issue of the existence of the Jewish State. It seemed entirely natural that the Jewish position, insistent upon a fully sovereign Jewish State, rejected any suggestion of restriction upon its authority to determine its own immigration policy. The Arabs, on the other hand, rejecting entirely the concept of the Jewish State, also denied the right of Jewish immigration into an Arab-dominated Palestine. The settlement of this issue could minimize the international importance of the immigration issue. However, proceeding from his observations, Folke Bernadotte was sure that the Jews, in the interest of promoting friendly relations with their Arab neighbours, were ready to do well, in defining their immigration policy, to take carefully into account the basis of Arab fears and to consider measures and policies designed to allay them.

Finally, the issue of Arab refugees remained on the agenda. This new and difficult element entered into the Palestine problem as a result of the exodus of more than 300,000 Arabs from their former homes in Palestine. The separate part III of Progress report A/648 of UN Mediator in Palestine to UN Secretary General of September 16th, 1948 was devoted to the measures being taken or contemplated to cope with this problem. Bernadotte considered it essential to face and solve the question of their ultimate resettlement, either in their former abodes or elsewhere. In fact, all the documents issued from the pen of UN Mediator affirmed that the right of the refugees to return to their homes if they so desire must be safeguarded. Nevertheless, it was acknowledged that, whether or not this right was exercised, most of these refugees would require assistance in some degree to re-establish themselves.

These were the main conclusions drawn by Count Bernadotte that characterized the situation in Palestine at that time. In Report A/648 he emphasized he didn't consider his authority ample enough to recommend the UN members should follow the certain suggested course of actions on the issue of Palestine, because it remained in the area of responsibility of the members themselves acting through the appropriate organs. In his role as UN Mediator, however, it was inevitable that Bernadotte should accumulate information and draw conclusions from his experience which might well be of assistance to the members of the United Nations Organization in charting the future course of action on Palestine.

Through the medium of his Progress report Bernadotte acquainted the M UN members with certain conclusions on the means of peaceful adjustment which had evolved from the frequent consultations with Arab and Jewish authorities in the summer 1948, as well as from his personal appraisal of the present Palestinian scene. Since in the course of his intensive efforts to achieve agreement between Arabs and Jews UN Mediator had not devised any definite formula containing the basis for suggestions that could be immediately approved by both parties at odds, he didn't consider himself entitled to offer the aggregate of his conclusions as such basis. However, he was convinced that it was possible at that stage to formulate a proposal which, if firmly approved and strongly backed by the General Assembly, would not be forcibly resisted by either party. Moreover, Count Bernadotte's position was based on the confidence that the Security Council would stand firm in its Resolution S/902 of July 15th, 1948 [10] stating that military action shall not be employed by either party in the Palestine dispute.

\section{SeCOnd Plan of Bernadotte}

The conclusions drawn by UN Mediator and able, in his opinion, to create a reasonable, just and effective foundation for conflict resolution in Palestine put together the Second plan of Folke Bernadotte. The plan was as follows.

1) Since the Security Council, under pain of sanctions given in Chapter VIII of UN Charter, had forbidden further employment of military action in Palestine as a means of settling, the dispute should have been pronounced formally ended either by mutual agreement of the parties or, failing that, by the United Nations. The existing indefinite truce should have been superseded by a formal peace or at the minimum, armistice which would involve either complete withdrawal and demobilization of armed forces or their wide separation by creation of broad demilitarized zones under United Nations supervision.

2) The frontiers between the Arab and Jewish territories, in the absence of agreement between Arabs and Jews, should have been established by the United Nations and delimited by a technical boundaries commission appointed by and responsible to the United Nations with the following revisions in the boundaries broadly defined in Resolution 181 of the General Assembly of November 29th, 1947 in order to make them more equitable, workable and consistent with existing realities in Palestine. The main territorial arrangements here included the following: 
- The area known as the Negeb, south of a line running from the sea near Majdal east-southeast to Faluja (both of which places would be in Arab territory), should have been defined as Arab territory;

- The frontier should have run from Faluja north northeast to Ramleh and Lydda (both of which places would be in Arab territory), the frontier at Lydda then following the line established in Resolution 181;

- Galilee should have been defined as Jewish territory.

3) The disposition of the territory of Palestine not included within the boundaries of the Jewish State should have been left to the governments of the Arab States in full consultation with the Arab inhabitants of Palestine, with the recommendation, however, that in view of the historical connection and common interests of Transjordan and Palestine there would be compelling reasons for merging the Arab territory of Palestine with the territory of Transjordan, subject to such frontier rectifications regarding other Arab States as may be found practicable and desirable.

4) The United Nations, by declaration or other appropriate means, should have undertaken to provide special assurance that the boundaries between the Arab and Jewish territories would be respected and maintained, subject only to such modifications as may be mutually agreed upon by parties concerned.

5) The port of Haifa, including the oil refineries and terminals, and without prejudice to their inclusion in the sovereign territory of the Jewish State or the administration of the city of Haifa, should have been declared a free port, with assurances of free access for interested Arab countries and an undertaking on their part to place no obstacle in the way of oil deliveries by pipeline to the Haifa refineries whose distribution should have continued on the basis of the historical pattern.

6) The airport of Lydda should have been declared a free airport with assurance of access to it and employment of its facilities for Jerusalem and interested Arab countries.

7) The City of Jerusalem understood as covering the area defined in Resolution 181 should have been treated separately and should have been placed under effective United Nations control with maximum feasible local autonomy for its Arab and Jewish communities with full safeguards for the protection of the Holy Places and sites and free access to them and for religious freedom.

8) The right of unimpeded access to Jerusalem, by road, rail or air, should have been fully respected by all parties.

9) The right of the Arab refugees to return to their homes in Jewish-controlled territory at the earliest possible date should have been affirmed by the United Nations, and their repatriation, resettlement and economic and social rehabilitation, as well as payment of adequate compensation for the property of those choosing not to return, should have been supervised and assisted by the United Nations conciliation commission described below.

10) The political, economic, social and religious rights of all Arabs in the Jewish territory of Palestine and of all Jews in the Arab territory of Palestine should have been fully guaranteed and respected by the authorities. The conciliation commission provided for in the following paragraph should have supervised the observance of this guarantee. It should have also lent its good offices, on the invitation of the parties, to any efforts toward exchanges of populations with a view to troublesome minority problems, and on the basis of adequate compensation for property owned.

11) In view of the special nature of the Palestine problem and the dangerous complexities of Arab-Jewish relationships, the United Nations should have established a Palestine conciliation commission. This commission appointed for a limited period should have been responsible to the United Nations and act under its authority. The commission assisted by such United Nations personnel as may prove necessary, should have undertaken:

- To employ its good offices to make such recommendations to the parties or to the United Nations, and to take such other steps as may be appropriate, with a view to ensuring the continuation of the peaceful adjustment of the situation in Palestine;

- Such measures as it might consider appropriate in fostering the cultivation of friendly relations between Arabs and Jews;

- To supervise the observance of such boundary, road, railroad, free port, free airport, minority rights and other arrangements as may be decided upon by the United Nations;

- To report promptly to the United Nations any development in Palestine likely to alter the arrangements approved by the United Nations in the Palestine settlement or to threaten the peace of the area.

TABLE I: COMPARISON OF THE TWO PLANS OF FOLKE BERNADOTTE

\begin{tabular}{|c|c|c|}
\hline Criteria & First Plan (June 1948) & Second Plan (September 1948) \\
\hline Form of government in Palestine & $\begin{array}{l}\text { Union comprising two members, one Arab } \\
\text { and one Jewish. } \\
\text { The functions and authority of the Union } \\
\text { to be exercised through a central council and } \\
\text { such other organs as the members of the Union } \\
\text { may determine. } \\
\text { Each member of the Union may exercise } \\
\text { full control over its own affairs including its } \\
\text { foreign relations. }\end{array}$ & $\begin{array}{l}\text { Any effective economic, political or } \\
\text { territorial unity in Palestine proved } \\
\text { impractical. } \\
\text { Existence of the independent state of } \\
\text { Israel was a given fact. } \\
\text { Creation of a unitary Arab State in } \\
\text { Palestine, with full rights and guarantees for } \\
\text { the Jewish minority, appeared unrealistic. } \\
\text { The United Nations to establish, in view } \\
\text { of the special nature of the Palestine problem, a } \\
\text { Palestine conciliation commission for a limited } \\
\text { period to act under its authority. }\end{array}$ \\
\hline
\end{tabular}


Boundaries

Jewish immigration policy

Issue of Arab refugees
To be determined by negotiation and definitively fixed by a boundaries commission.

Main territorial arrangements:

- inclusion of the whole or part of the Negev in Arab territory;

- inclusion of the whole or part of Western Galilee in Jewish territory.
To be established, in the absence of agreement between Arabs and Jews, by the United Nations and delimited by a technical boundaries commission.

The United Nations to provide special assurance that the boundaries between the Arab and Jewish territories would be respected and maintained, subject only to such modifications as may be mutually agreed upon by parties concerned.

Main territorial arrangements:

- Negev to be defined as Arab territory;

- frontier to run from Faluja north northeast to Ramleh and Lydda (both of which places would be in Arab territory), the frontier at Lydda to follow the line established in Resolution 181;

- Galilee to be defined as Jewish territory;

- territory of Palestine not included within the boundaries of the Jewish State to be left to the governments of the Arab States in full consultation with the Arab inhabitants of Palestine, with the recommendation to merge the Arab territory of Palestine with the territory of Transjordan, subject to practicable and desirable frontier rectifications regarding other Arab States.

The City of Jerusalem to be treated separately and be placed under effective United Nations control with maximum feasible local autonomy for its Arab and Jewish communities with full safeguards for the protection of the Holy Places and sites and free access to them and for religious freedom. The right of unimpeded access to Jerusalem to be fully respected by all parties.
Inclusion of the City of Jerusalem in Arab territory, with municipal autonomy for the Jewish community and special arrangements for the protection of the Holy Places.
No special provisions. The Jewish position rejected any suggestion of restriction upon its authority to determine its own immigration policy. The Arabs denied the right of Jewish immigration into an Arab-dominated Palestine. However, the Jews, in the interest of promoting friendly relations with their Arab neighbours, were allegedly ready to take carefully into account the basis of Arab fears and to revise their immigration policy accordingly. binding on the member whose policy is at issue.

Affirmation of the right of the Arab refugees to return to their homes in Jewish-controlled territory at the earliest possible date. Their repatriation, resettlement and economic and social rehabilitation, as well as payment of adequate compensation for the property of those choosing not to return, to be supervised and assisted by the United Nations conciliation commission

Recognition of the right of residents of Palestine who had left their normal places of abode to return to their homes without restriction and to regain possession of their property.
The political, economic, social and religious rights of all Arabs in the Jewish territory of Palestine and of all Jews in the Arab territory
Human rights
Religious and minority rights to be fully protected by each member of the Union and guaranteed by the United Nations. 
of Palestine to be fully guaranteed and respected by the authorities. The conciliation commission to supervise the observance of this guarantee.

That was the essence of the Second plan of Folke Bernadotte. According to the Jews, the above mentioned suggestions to a large extent copied the plan of the so-called Peel Commission of $1937^{3}$ and were, in fact, aimed at broadening the territory controlled by the Arab party.

On September 17th, 1948, the next day after the submission of Progress report A/648 UN Mediator in Palestine Count Folke Bernadotte was assassinated by the militants of the Jewish extremist clandestine group "Lehi", but the accused of the murder were set free soon after the arrest (See Table I).

\section{CONCLUSION}

The significance of Folke Bernadotte's work cannot be underestimated. Not only did he undertake certain effective steps to cease fire soon after the beginning of the first Arab-Israeli war, but also he developed an aggregate of suggestions concerning the conflict resolution in Palestine that took into account the positions and interests of both parties. In the existing realities it was exceptionally difficult to find the basis for a peace accord that would automatically win approval by both the governments of the Arab states and Tel Aviv. Nevertheless, putting forward suggestions and holding negotiations with both parties Folke Bernadotte repeatedly underlined that he didn't pretend to finally entrench the offered measures. The First and the Second plans of Bernadotte in substance were the attempts of the search of probable foundation for compromise and identifying the principled demands of the parties.

The reason for Bernadotte's assassination was obviously the fervent denial of his Second plan given in Progress report A/648 of September 16th, 1948 to UN Secretary General by certain representatives of the Jews who characterized it as strictly pro-Arab and pretending to acquire the force of law soon with the UN approval. Nevertheless, nothing in the text of the report and the plan proved such position was reasonable. Nor did anything give reason for supposing that the Second plan of Folke Bernadotte, had it been submitted for review and discussion of the official representatives of the parties at odds in Palestine, as well as the United Nations Organization members, would have not serve as the basis for the search of conflict resolution in accordance with the task set by Bernadotte. It might well be that the suggestions of UN Mediator in Palestine, if developed and modified with respect to the principled interests of Arabs and Jews, could have become the foundation for the effective peace accord already at the described stage of the Arab-Israeli conflict.

\footnotetext{
${ }^{3}$ The report of British royal commission that came in November 1936 to trusteeship Palestine for putting down the Arab revolt was published on July $7^{\text {th }}, 1937$ and contained inter alia the suggestions on partition of Palestine and creation of a single Arab state including West Bank of Jordan, Negev, the neighborhoods of Gaza, and Transjordan.
}

In any case some discrepancy and misconception were committed at the initial stage of reconciliation process in Palestine. The careful analysis of Folke Bernadotte's suggestions allows avoiding this stalemate in the future and possibly successfully shaping a final peace accord between Arabs and Jews.

\section{REFERENCES}

[1] UN General Assembly Resolution 181 on the Future Government of Palestine (Partition Plan), November 29, 1947.

[2] UN General Assembly Resolution 186 (S-2) Concerning the Appointment of a UN Mediator, May 14,1948.

[3] UN Security Council Resolution 48, April 23, 1948

[4] R. Hewins, Count Folke Bernadotte: His Life and Work, Minneapolis: T. S. Denison \& Company, 1950.

[5] A. Ilan, Bernadotte in Palestine, 1948: A Study in Contemporary Humanitarian Knight-Errantry, New York: St. Martins's Press, 1989.

[6] J. Quigley, Palestine and Israel: A Challenge to Justice, Durham, NC Duke University Press; London, 1990.

[7] UN Mediator on Palestine Count Folke Bernadotte, Suggestions Presented to the Two Parties, 27 June 1948.

[8] UN Mediator Count Folke Bernadotte, Progress Report Submitted to the UN Secretary General in Pursuance of UNGA Resolution 186 (S-2) of 14 May 1948, 16 September 1948.

[9] UN Mediator on Palestine, Report to the Security Council S/888, 12 July 1948.

[10] UN Security Council Resolution S/902, July 15,1948.

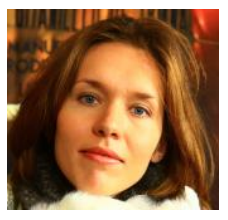

Anna N. Osipenko was born in Berezniki, Perm region (Russian Federation) on August $16^{\text {th }}$, 1988. In 2013 she got a degree with distinction in international relations at Lobachevsky State University of Nizhni Novgorod, Faculty of International Relations. At the present moment she is a $\mathrm{PhD}$ student in political problems of international relations, global and regional development at Lobachevsky State University of Nizhni Novgorod, Institute of international relations and world history, chair of world diplomacy and international law. Her main field of research is the initial stage of institutional peace process in Palestine, particularly the mission of Count Folke Bernadotte.

From March to November 2014. Ms. Osipenko was employed in the position of a administrative assistant, from November 2014 to April 2015 in the position of a senior administrative assistant in the Russian Union of Exhibitions and Fairs. Previous research interests when a student included European parliamentarianism and the constitutional aspects of interaction of legislative authorities of Denmark and Sweden with the European parliament. 